\title{
Virus-Induced Diabetes Mellitus in Mice and the Thymus-Dependent Immune System
}

\author{
K. Buschard, N. Hastrup, and J. Rygaard \\ Pathological-Anatomical Institute, Kommunehospitalet, Copenhagen, Denmark
}

\begin{abstract}
Summary. The present study concerns the effect of the experimental diabetogenic encephalomyocarditis (EMC) virus on normal and athymic nude mice of $B A L B / c$ origin. The effect of simultaneous immunosuppressive pharmacological treatment with a derivative of cyclophosphamide in a relatively low dose ( $3 \mathrm{mg} / \mathrm{mouse})$ was also studied. After inoculation with EMC virus, $36 \%$ of the normal mice, but none of the nude mice, developed diabetes mellitus and $93 \%$ of the normal mice, but none of the nude mice, developed paresis of one or more leg(s). When lower doses of EMC virus were given, few or none of the normal mice developed diabetes or paresis. After treatment with a cyclophosphamide-derivative, the number of paralysed mice increased. EMC virus in abundant amounts could be isolated from the pancreas and heart of all virus-inoculated mice, including the non-diabetic nude mice.
\end{abstract}

Antibodies against EMC virus were found in all groups of virus-inoculated mice, although only in small amounts in nude and immunosuppressed normal mice. Histological examination revealed no significant differences between the islets of Langerhans of the experimental mice, diabetic as well as non-diabetic, and the control mice with respect to lymphocytic infiltration.

It is concluded that the thymus-dependent immune system seems to be of decisive importance for the development of diabetes in this virus model.

Key words: Encephalomyocarditis virus, diabetes mellitus, athymic nude mice, the thymus-dependent immune system, cyclophosphamide.
This investigation concerns the effect of the experimental diabetogenic encephalomyocarditis (EMC) virus (M-strain) on the athymic nude mouse and on the normal, haired mouse of BALB/c origin. The purpose of the present investigation was to study the importance of the immune system in the development of diabetes in this animal model. Several human investigations have suggested that the immune system might play a pathogenic role in Type 1 (insulin-dependent) diabetes mellitus. Many patients with Type 1 diabetes possess humoral auto-antibodies directed against the islet-cell cytoplasm [1] and/or antibodies directed against the surface of the islet B cells [2]. Patients with Type 1 diabetes often exhibit a positive reaction in the leucocyte migration test using different pancreatic homogenates [3]. Various immunological phenomena have been described, in which Type 1 diabetic subjects differ from healthy control individuals. For example, there is reduced suppressor cell activity at the time of diagnosis [4], and an increase in the number of $\mathrm{K}$ cells [5]. The EMC virus has been shown to be diabetogenic in several mouse strains, with quite large variation within and between strains [6]. Earlier studies in the C57 mouse strain demonstrated a lack of diabetogenic effect by the EMC virus on athymic nude mice, whereas abnormal glucose tolerance curves were obtained from heterozygous littermates, and from homozygous normal mice [7].

The present investigation utilized BALB/c mice and included an evaluation of blood glucose, virus studies, virus antibody determinations, and histological investigation. The effect of immunosuppressive treatment with a derivative of cyclophosphamide was also studied.

\section{Materials and Methods}

Two strains of mice were investigated: (1) 145 approximately 8-weekold, normal, haired, male BALB/c/BOM mice, and (2) 29 approximately 8-week-old, $n u / n u$, male BALB/c/BOM mice (11th backcross generation of a gene transfer to $\mathrm{BALB} / \mathrm{c} / \mathrm{BOM}$ ). The mice were $\mathrm{di}$ vided into the following treatment groups: group 1: 46 normal mice injected with virus in a concentration and amount described below; group 2: 25 normal mice injected with one-tenth of the amount of virus employed for group 1 (dissolved in the same volume of vehicle); group 3: 20 normal mice injected with 1/1000th of the amount of virus employed for group 1 (dissolved in the same volume of vehicle); group 4: 20 normal mice injected with virus as in group 3 but also treated with suphosphamide (Cytimun, Asta/Schering, Copenhagen, 
Table 1. Glycosuria and blood glucose measurements in the different groups of mice

\begin{tabular}{|c|c|c|c|c|c|c|c|}
\hline \multirow[t]{2}{*}{ Groups } & \multirow{2}{*}{$\begin{array}{l}\text { Virus dose } \\
\text { (group } 1=1 \text { ) }\end{array}$} & \multicolumn{3}{|c|}{ Mice showing glycosuria } & \multirow{2}{*}{$\begin{array}{l}\text { Mice not showing } \\
\text { glycosuria } \\
\text { blood glucose } \\
(\mathrm{mmol} / 1)\end{array}$} & \multicolumn{2}{|c|}{ Mice showing paresis } \\
\hline & & $\begin{array}{l}\text { onset after } \\
\text { virus inoculation } \\
\text { (days) }\end{array}$ & $\%$ & $\begin{array}{l}\text { blood } \\
\text { glucose } \\
(\mathrm{mmol} / 1)\end{array}$ & & $\begin{array}{l}\text { onset } \\
\text { after virus } \\
\text { inoculation } \\
\text { (days) }\end{array}$ & $\%$ \\
\hline 1 Normal mice $(n=46)$ & 1 & $5-10$ & 36 & $23 \pm 3$ & $8 \pm 1$ & $4-10$ & 93 \\
\hline 2 Normal mice $(n=25)$ & 0.1 & $6-16$ & 28 & $17 \pm 1$ & $8 \pm 1$ & $5-10$ & 84 \\
\hline 3 Normal mice $(n=20)$ & 0.001 & - & 0 & - & $9 \pm 1$ & $6-14$ & 24 \\
\hline $\begin{array}{l}4 \text { Normal mice treated } \\
\text { with suphosphamide } \\
(n=20)\end{array}$ & 0.001 & - & 0 & - & $8 \pm 1$ & $4-67$ & 63 \\
\hline 5 Nude mice $(n=19)$ & 1 & - & 0 & -- & $7 \pm 1$ & - & 0 \\
\hline 6 Control mice $(n=44)$ & 0 & - & 0 & - & $8 \pm 1$ & - & 0 \\
\hline
\end{tabular}

Results expressed as mean \pm SEM or range, numbers of mice in parentheses

Denmark); group 5: 19 nude mice injected with virus as in group 1; group 6: 20 normal mice injected with virus-free vehicle, 14 normal mice injected with virus-free vehicle and also treated with suphosphamide, and 10 nude mice injected with virus-free vehicle.

All of the mice were purchased from Gl. Bomholtgaard Laboratory, Animal Breeding and Research Centre, Ry, Denmark. The mice were reared under specified-pathogen-free conditions and were kept during experiments under conventional conditions at the Royal Veterinary and Agricultural University, Copenhagen. Autoclaved food pellets (Gl. Bomholtgaard) and sterile drinking water were provided ad libitum. The mice were observed daily during the first 3 weeks and at longer intervals thereafter. Occurrence of glycosuria as well as paresis were recorded.

\section{Virus, Virus Assay and Virus Inoculation}

An M-strain of the encephalomyocarditis virus, kindly supplied by Dr. J. E. Craighead, known to be diabetogenic [8], was used. The same strain has been used in two earlier investigations [7,9]. A sixth passage batch of virus was titrated in L cells (established cell line of mouse fibroblasts) to a titre of $10^{5.5} \mathrm{TCID}_{50}$ (tissue culture infective doses) $/ \mathrm{ml}$. All of the mice were inoculated subcutaneously with $0.2 \mathrm{ml}$ vehicle, for group 1 mice this contained $10^{4.0} \mathrm{TCID}_{50}$. Control animals were inoculated with the suspension medium alone.

\section{Immunosuppression}

Group 4 and some group 6 mice were treated with suphosphamide (Cytimun, Asta/Schering, Copenhagen, Denmark). This compound is a derivative of cyclophosphamide and is pharmacologically immunosuppressive. Following virus administration each mouse was injected IP daily for 6 days with $0.5 \mathrm{ml}$ of a solution containing $1 \mathrm{mg} / \mathrm{ml} \mathrm{su}$ phosphamide in physiological saline. Fresh solutions were prepared daily.

\section{Animal Sacrifice}

The mice were anaesthetized with ether and then bled to death by cutting the axillary vein and artery. Immediately thereafter, the pancreas and heart were removed. The blood collected during sacrifice was analyzed enzymatically for blood glucose concentration using a glucose oxidase method [10]. Glycosuria was determined with Testape (Lilly, Indianapolis, Indiana, USA). Heart and pancreas tissues removed after sacrifice were placed in Hanks' buffer and homogenized immediately in a sand mortar. The amount of virus present was determined by titration in $\mathrm{L}$ cell cultures employing tenfold dilution steps and three cultures per dilution. Each value represents one mouse (Fig. 1).

\section{Virus Antibodies}

The mice were examined for the presence of neutralizing antibodies against EMC virus. The blood examined during the first 3 weeks was derived from sacrificed mice, and thereafter from blood samples of about $100 \mu \mathrm{l}$ withdrawn from the paraorbital venous plexus. Each antibody determination was carried out as a neutralization test performed in $\mathrm{L}$ cell cultures against $100 \mathrm{ID}_{50}$ (infective doses) of EMC virus. Serial dilutions with a factor of 5 were each inoculated (three cultures per dilution). Each value represents one mouse (Figs. 2 and 3 ).

\section{Light Microscope Studies}

The tail of the pancreas was removed from the remainder of the gland after animal sacrifice and immediately fixed in $10 \%$ buffered formalin and embedded in paraffin. Sections (5 $\mu$ thick) were cut and stained with haematoxylin-eosin, and examined without knowledge of which group the mouse belonged to. Twelve diabetic mice, 15 non-diabeticvirus-infected mice and 10 control mice were studied. The diabetic mice were examined, as soon as diabetes was established, between 6 and 10 days after the virus inoculation.

\section{Electron Microscope Studies}

Immediately after removal of the gland, approximately $1 \mathrm{~mm}^{3}$ of the caudal pancreas was fixed in phosphate-buffered, $3 \%$ glutaraldehyde (pH 7.4). The specimens were postfixed in $1 \% \mathrm{OsO}_{4}$, dehydrated in alcohol, embedded in Epon (Bie \& Berntsen, Copenhagen, Denmark), sectioned with a diamond knife and stained with uranyl acetate and lead citrate. The specimens were examined with a Hitachi $7 \mathrm{~S}$ electron microscope.

\section{Statistical Analyses}

Experimental data are presented as mean \pm SEM. The significance of differences was evalutated by Fisher's exact test or by the MannWhitney U-test. The level of type 1 error $(2 \alpha)$ was 0.05 .

Results

\section{Clinical Observations and Blood Glucose Determinations}

Results are presented in Table 1 . Fourteen mice in group 1 and seven mice in group 2 developed glycosuria. These mice composed $36 \%$ and $28 \%$, respectively, 
of the total number of mice in the two groups when the first mouse became diabetic. These findings are significantly different from all of the remaining groups, in which none of the mice developed glycosuria $(p<0.01$, $p<0.05$, respectively). Group 1 mice developed glycosuria 5-10 days after virus inoculation (mean blood glucose $23 \pm 3 \mathrm{mmol} / \mathrm{l}$ ), whereas the blood glucose level on sacrifice of the rest of the mice in group 1 (which did not develop glycosuria) was $8 \pm 1 \mathrm{mmol} / \mathrm{l}$. Group 2 mice developed glycosuria 6-16 days after virus inoculation (mean blood glucose level $17 \pm 1 \mathrm{mmol} / 1$ ) compared with $8 \pm 1 \mathrm{mmol} / 1$ for the group 2 mice without glycosuria. The average blood glucose values of all the remaining mice on sacrifice ranged between $7 \pm 1$ and $9 \pm 1 \mathrm{mmol} / \mathrm{l}$.

The results indicate that approximately one-third of the normal mice inoculated with a relatively large dose of EMC virus (groups 1 and 2) developed diabetes. This is in contrast to the remaining mice, particularly the nude mice, which did not develop diabetes, even though they received a high dosage of virus.

A large proportion of the normal mice inoculated with virus (groups 1-4) developed paresis, while this did not occur in any of the nude or control mice. The paresis affected one or both rear legs, and even occurred in the front legs in some mice, in which case the animal was sacrificed. Ninety-three percent of the mice in group 1 developed paresis. This was significantly higher than in group $3(p<0.002)$, group $4(p<0.02)$ and the control group $(p<0.002)$. A similar proportion $(84 \%)$ of the mice in group 2 also developed paresis, which was significantly greater than in group 3 and the control group (both $p<0.002$ ), but not significantly different from group 4 , in which $63 \%$ became paralysed. Despite the fact that both group 3 and group 4 mice were injected with the same dosage of virus, significantly fewer mice in group $3(24 \%)$ developed paresis than in group 4 , where the animals were also treated with suphosphamide $(p<0.05)$. The percentage of mice with paresis in group 4 was significantly higher than in the control group $(p<0.002)$, which was not the case for the mice in group $3(0.05<p<0.10)$. The paresis appeared between days 4 and 10 in group 1 (mean $5 \pm 1$ days) and up to day 14 in group 3 (mean $9 \pm 2$ days). Among the immunosuppressed mice paresis appeared as late as 67 days after inoculation (mean $17 \pm 5$ days).

Thus, while paresis occurred in a substantial proportion of the normal mice, it did not develop at all in the nude mice. Immunosuppressive treatment increased the number of paralysed mice.

\section{Virus Cultivations}

The cultivation results on heart and pancreas from mice in groups 1, 3-5 are displayed logarithmically in Figure 1. In group 1 mice (Fig. 1 A) virus could be demonstrated in the pancreas already on the first day after virus inoculation, the maximum titre was detected after
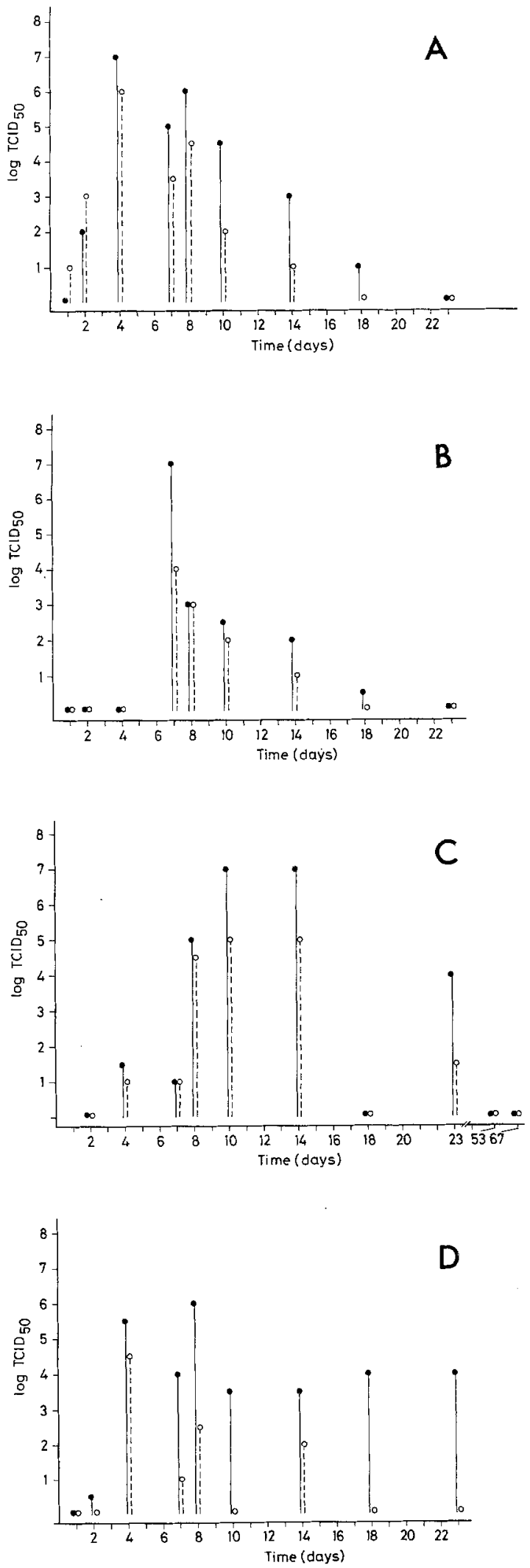

Fig. 1. The results of virus cultivations from heart and pancreas. TCID $=$ Tissue Culture Infective Doses; $-{ }_{-}=$heart, $\mathrm{O}_{----}=$pancreas.

A, group 1; normal mice with full dose of virus

B, group 3; normal mice with $1 / 1000$ th dose of virus

C, group 4 ; as group 3 but treated with suphosphamide

$\mathrm{D}$, group 5; nude mice with full dose of virus 


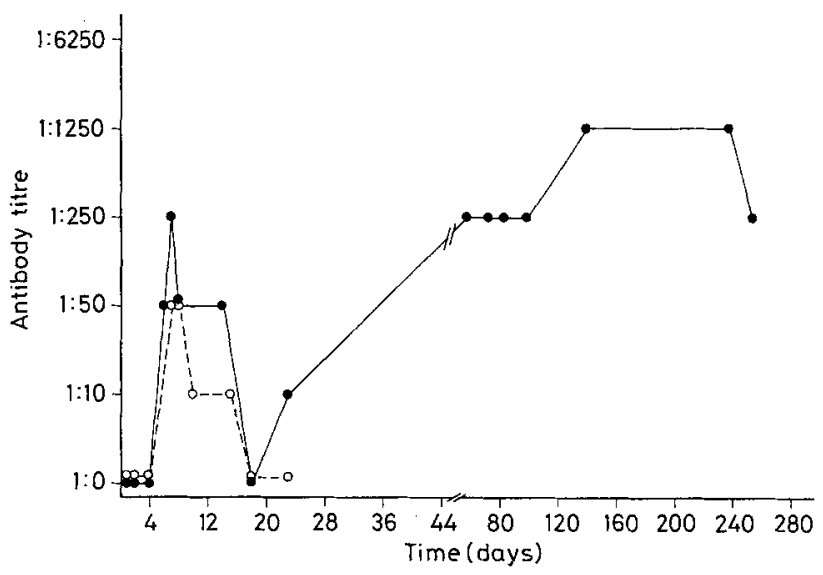

Fig. 2. The results of virus antibody determinations in group 1 $(-1)$ and group $5\left(\mathrm{O}_{--} \mathrm{O}\right)$

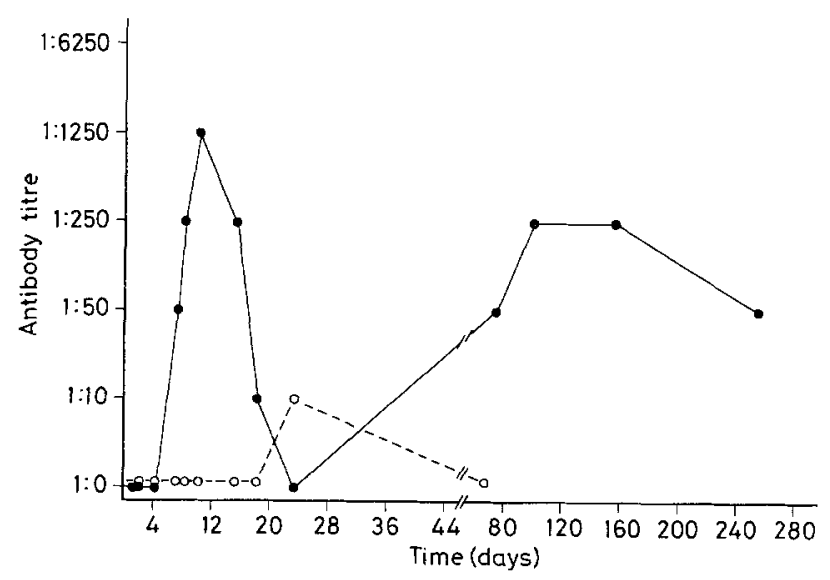

Fig. 3. The results of virus antibody determinations in group 3 $(\longrightarrow)$ and group $4\left(\mathrm{O}_{--\infty} \mathrm{O}\right)$

4 days, and the last positive finding was 18 days after virus injection. In group 3 mice (Fig. 1 B) the first virus demonstration occurred 7 days after virus inoculation which also was the time of the measured maximum titre, while the last positive isolation occurred after 18 days. Group 4 mice (Fig. 1 C), which also received suphosphamide, exhibited a somewhat different picture. The maximum titre was found after 10-14 days, and quite a high titre was still present 23 days after inoculation. In the nude mice (group 5, Fig. 1D) the maximum titre was observed in the pancreas 4 days after injection and in the heart tissue 8 days after injection. As late as 23 days after injection virus could still be demonstrated in nude mice.

Thus, virus in abundant amounts could be demonstrated in all types of mice that were inoculated, even the nude mice which were not clinically affected. The earliest virus demonstrations were obtained from mice that were injected with a relatively large dosage of virus, and virus cultivation of the longest time after inoculation were obtained from immuno-defective mice (nude mice) and immunosuppressed mice. All attempts to demonstrate virus in control mice were negative.

\section{Virus Antibody Determinations}

The results of antibody studies on normal mice (group 1) and nude mice (group 5), which both received the same high dosage of virus, are presented in Figure 2. Both nude and normal mice began producing measurable amounts of antibody 1 week after virus inoculation. Antibody formation in nude mice was small and remained detectable for only 15 days. On the other hand, normal mice produced relatively large amounts of antibody but then diminished markedly after 2-3 weeks, followed by a titre increase. Even 8 months after the virus inoculation, a relatively high titre of antibody could still be detected.

Figure 3 shows the results of antibody measurements from groups 3 and 4, which both had been inoculated with relatively low dosages of virus. The curve for group 3 mice resembles the corresponding curve for group 1 mice. The mice in group 4, which additionally received immunosuppressive treatment, did not produce measurable antibodies until after 23 days and they became negative again after 67 days.

\section{Histological Studies}

By light microscopy no difference was found between the virus treated, diabetic or non-diabetic mice, and the control mice, with respect to the number of lymphocytes in the islets of Langerhans. Apart from a few lymphocytes detected in one or more of the islets in less than $15 \%$ of the examined mice, randomly distributed among the different groups, including the control group, no lymphocytic infiltration was seen.

By electron microscopy some of the islet B-cells in the diabetic mice were found to contain fewer granules than B-cells from the control mice. In diabetic mice myelin bodies were seen in acinar cells as well as in B-cells, almost exclusively in mitochondria. No macrophages or frank necrosis were observed.

\section{Discussion}

The present investigation has shown that athymic nude mice do not - in contrast to a substantial proportion of normal mice - develop diabetes mellitus after infection with EMC virus despite the demonstration that both the nude as well as the normal mice were unequivocally infected. Therefore, it seems reasonable to assume that diabetes may result as a reaction of the thymus-dependent immunological system to the virus infection, rather than as a result of the virus infection per se.

This conclusion is consistent with a similar investigation which used C57 mice. Nude C57 mice - in con- 
trast to normal C57 mice - did not develop glucose intolerance after infection with EMC virus [7]. Also a later study by Jansen et al. found no development of diabetes in nude mice of $\mathrm{BALB} / \mathrm{c}$ origin in contrast to normal mice of the same strain [11]. This study did not mention any viral measurements or histology. However, although these findings are confirmed we have found important differences between $\mathrm{C} 57$ and $\mathrm{BALB} / \mathrm{c}$ mice. C57 mice developed less severe glucose intolerance compared with the BALB/c mice. Another major difference between BALB/c and C57 mice, after injection with the same amount of EMC virus, appeared to be the time of emergence of the diabetic state, appearing about 1 week after injection in BALB/c mice. At this time virus in abundant amounts could be detected, but no virus could be demonstrated in C57 mice when they developed diabetes about 2-3 weeks after inoculation [9].

Immunosuppressive treatment of mice with suphosphamide seemed to increase the proportion of mice which became paralysed. In a similar study using $\mathrm{DBA}_{2}$ mice, none of the mice showed paresis, but increased blood glucose values were seen when a cyclophosphamide derivative was given together with EMC virus [12]. It is known that suppressor cells are particularly sensitive to cyclophosphamide treatment $[13,14]$, and it can therefore be suggested that the increased percentage of paralysed mice could result from an inhibiting effect of suphosphamide on suppressor cells. This would be in accordance with the observation that the spontaneous development of autoimmune disease in NZB mice may depend on a deficiency of suppressor cells [15].

No significant lymphocyte infiltration was found in histological examinations of pancreas tissue from the diabetic mice in the present investigation. In CD-1 mice a moderate infiltration of mononuclear cells has been found after EMC virus injection $[16,17]$. The infiltrate was found only in some of the islets, mostly in the periphery and in the surrounding tissue, including the vessels [16].

It can be concluded that, although the thymus-dependent immune system seems to be of decisive importance for the development of diabetes in this virus model, the primary mechanism for affecting the islet B cells seems not to be a massive lymphocytic infiltration in the islets. The involvement of other immunological mechanisms than a classical type IV reaction should therefore be considered.

Acknowledgements. We wish to thank Miss T. Vang for excellent technical assistance, and Drs. B. Marner and B. Hainau for help in interpretating the electron microscopy. Cytimun was kindly placed at our disposal by Asta/Schering, Copenhagen, Denmark. The study was supported in part by grants from the Michaelsen Foundation and the Danish Medical Research Council, grants no. 512 - 15659 and no. 512 $-16185$.

\section{References}

1. Bottazzo GF, Florin-Christensen A, Doniach D (1974) Islet-cell antibodies in diabetes mellitus with autoimmune polyendocrine deficiencies. Lancet 2: 1279-1283

2. Lernmark $\AA$, Freedman ZR, Hofmann C, Rubinstein AH, Steiner DF, Jackson RL, Winter RJ, Traisman HS (1978) Islet-cell-surface antibodies in juvenile diabetes mellitus. N Engl J Med 299: 375-380

3. Nerup J, Andersen OO, Bendixen G, Egeberg J, Gunnarsson R, Kromann H, Poulsen JE (1974) Cell-mediated immunity in diabetes mellitus. Proc Roy Soc Med 67: 506-513

4. Buschard K, Madsbad S, Rygaard J (1980) Depressed suppressor cell activity in patients with newly diagnosed insulin-dependent diabetes mellitus. Clin Exp Immunol 41:25-32

5. Pozzilli P, Gorsuch A, Sensi M, Bottazzo GF, Cudworth AG (1979) Evidence for raised K cell levels in Type-1 diabetes. Lancet 2: 173-175

6. Boucher DW, Hayashi K, Rosenthal J, Notkins AL (1975) Virusinduced diabetes mellitus. III. Influence of the sex and strain of the host. J Infect Dis 131: 462-466

7. Buschard K, Rygaard J, Lund E (1976) The inability of a diabetogenic virus to induce diabetes mellitus in athymic (nude) mice. Acta Path Microbiol Scand Sect C 84: 299-303

8. Craighead JE, McLane MF (1968) Diabetes mellitus: Induction in mice by encephalomyocarditis virus. Science 162:913-914

9. Buschard K (1978) Passive transfer of virus induced diabetes mellitus with spleen cells. Acta Pathol Microbiol Scand Sect C 86: 29-32

10. Trinder $P$ (1969) Determination of glucose in blood using glucose oxidase with an alternative oxygen acceptor. Ann Clin Biochem 6: $24-27$

11. Jansen FK, Thurneyssen O, Müntefering H (1979) Virus induced diabetes and the immune system II - Evidence for an immune pathogenesis of the acute phase of diabetes. Biomedicine 31:1-2

12. Jansen FK, Müntefering H, Schmidt WAK (1977) Virus induced diabetes and the immune system. I. Suggestion that appearance of diabetes depends on immune reactions. Diabetologia 13: 545-549

13. Röllinghoff M, Starzinski-Powitz A, Pfizenmaier K, Wagner $H$ (1977) Cyclophosphamide-sensitive T lymphocytes suppress the in vivo generation of antigen-specific cytotoxic T lymphocytes. J Exp Med 145: 455-459

14. Gill HK, Liew FY (1978) Regulation of delayed-type hypersensitivity III. Effect of cyclophosphamide on the suppressor cells for delayed-type hypersensitivity to sheep erythrocytes in mice. Eur J Immunol 8: 172-176

15. Steinberg AD, Gerber NL, Gershwin ME, Morton R, Goodman D, Chused TM, Hardin JA, Barthold DR (1975) Loss of suppressor $T$ cells in the pathogenesis of autoimmunity. In: Singhal SK, Sinclair NR st C (eds) Suppressor cells in immunity. International Symposium, May 1975. The University of Western Ontario, Canada, pp 174-181

16. Craighead JE (1975) The role of viruses in the pathogenesis of pancreatic disease and diabetes mellitus. Prog Med Virol 19: $161-214$

17. Wellmann KF, Amsterdam D, Brancato P, Volk BW (1972) Fine structure of pancreatic islets of mice infected with the $M$ variant of the encephalomyocarditis virus. Diabetologia 8: 349-357

Received: 17 December 1981

and in revised form: 26 May 1982

Dr. Karsten Buschard

Pathological-Anatomical Institute

Kommunehospitalet

DK-1399 Copenhagen $\mathrm{K}$

Denmark 